\title{
Identification of Cell Wall-Associated Proteins from Phytophthora ramorum
}

\author{
Harold J. G. Meijer, ${ }^{1}$ Peter J. I. van de Vondervoort, ${ }^{1}$ Qing Yuan Yin, ${ }^{2}$ Chris G. de Koster, ${ }^{2}$ \\ Frans M. Klis, ${ }^{2}$ Francine Govers, ${ }^{1}$ and Piet W. J. de Groot ${ }^{2}$ \\ ${ }^{1}$ Laboratory of Phytopathology, Plant Sciences Group, Wageningen University, Binnenhaven 5, NL-6709 PD Wageningen, \\ The Netherlands; ${ }^{2}$ Swammerdam Institute for Life Sciences, University of Amsterdam, Nieuwe Achtergracht 166, NL-1018 \\ WV Amsterdam, The Netherlands
}

Submitted 31 May 2006. Accepted 24 July 2006.

\begin{abstract}
The oomycete genus Phytophthora comprises a large group of fungal-like plant pathogens. Two Phytophthora genomes recently have been sequenced; one of them is the genome of Phytophthora ramorum, the causal agent of sudden oak death. During plant infection, extracellular proteins, either soluble secreted proteins or proteins associated with the cell wall, play important roles in the interaction with host plants. Cell walls of $P$. ramorum contain 1 to $1.5 \%$ proteins, the remainder almost exclusively being accounted for by glucan polymers. Here, we present an inventory of cellwall-associated proteins based on mass spectrometric sequence analysis of tryptic peptides obtained by proteolytic digestion of sodium dodecyl sulfate-treated mycelial cell walls. In total, 17 proteins were identified, all of which are authentic secretory proteins. Functional classification based on homology searches revealed six putative mucins or mucin-like proteins, five putative glycoside hydrolases, two transglutaminases, one annexin-like protein, the elicitin protein RAM5, one protein of unknown function, and one Kazal-type protease inhibitor. We propose that the cell wall proteins thus identified are important for pathogenicity.
\end{abstract}

Additional keywords: cell wall proteome.

The fungal cell wall is an essential organelle that enables cells to resist internal turgor pressures which, in appressoria of plant pathogens, may reach values up to $8 \mathrm{MPa}$ (Howard et al. 1991) The cell wall is also of vital importance for maintaining cell morphology, uptake of substances, interactions with plasma membrane proteins, signaling, and protection against adverse conditions in the cellular environment. The cell wall may function further as a barrier by preventing proteins from leaking into the medium and act as a scaffold for exposing cell wall proteins (CWPs) to the cell surface (De Groot et al. 2005). The large diversity of implicated biological roles of CWPs includes cell wall biosynthesis and adhesion. For pathogenic microorganisms, such as fungi and oomycetes, CWPs also can provide protection against host defense reactions (De Groot et al. 2004). Adhesion to host tissues is an important attribute in pathogenesis and, in many cases, indispensable for virulence (De Groot et al. 2005; Sundstrom 2002).

Many fungi have bilayered cell walls. The inner, electrontransparent layer is primarily composed of polysaccharides such as 1,3- $\beta$-glucan, 1,6- $\beta$-glucan, 1,3- $\alpha$-glucan, and chitin,

Corresponding author: H. J. G. Meijer; Telephone: +31 317483 403; Fax: +31 317483 412; E-mail: Harold.Meijer@wur.nl and is surrounded by an electron-dense layer, mainly comprising covalently bound mannosylated proteins (Klis et al. 2002). In a few ascomycetes, the CWP composition has been studied in detail using tandem mass spectrometry (De Groot et al. 2004; Yin et al. 2005). In baker's yeast (Saccharomyces cerevisiae) and the pleomorphic human pathogen Candida albicans, many of the CWPs are classified as carbohydrate- or glycan-modifying enzymes. In addition, adhesins, heme-binding proteins involved in iron uptake, and superoxide dismutases involved in environmental protection are found in the cell wall (De Groot et al. 2005). Most of the identified CWPs in S. cerevisiae and $C$. albicans are covalently bound glycosylphosphatidylinositol (GPI)-modified proteins. Typical features of GPI proteins are a canonical $N$-terminal signal peptide for secretion and a hydrophobic $C$-terminal region that functions as a signal peptide for the addition of a GPI membrane anchor (De Groot et al. 2005). GPI proteins in fungi have a unique characteristic depending on sequence features immediately upstream of the GPI-anchor attachment site. They may be cleaved from the plasma membrane and subsequently attached covalently to the cell wall glucan (De Groot et al. 2005). This covalent incorporation of GPI CWPs in the cell wall of $S$. cerevisiae and other ascomycetes was shown to be achieved by direct attachment to 1,6- $\beta$-glucan, which interconnects CWPs to the 1,3- $\beta$ glucan network (Kapteyn et al. 1996; Kollár et al. 1997). Such covalently linked CWPs can be solubilized by glucanases but not by treatment with $\mathrm{NaCl}$ or hot sodium dodecyl sulfate (SDS) solutions. Other proteins in S. cerevisiae and C. albicans are bound to the cell wall polysaccharide network through a linkage that is sensitive to treatment with mild alkali (De Groot et al. 2004; Ecker et al. 2006; Kapteyn et al. 1999; Yin et al. 2005).

Oomycetes are a unique group of fungal-like eukaryotes that includes notorious pathogens of plants and animals. The oomycete genus Phytophthora comprises over 70 species that all cause devastating plant diseases on a wide variety of commercially grown crops and in natural vegetations. Phytophthora ramorum is among the most destructive plant pathogens that have been discovered in the last decade. It originally was described as a pathogen on Rhododendron and Viburnum spp. (Werres et al. 2001) and subsequently found to be responsible for the sudden oak death syndrome, in particular, on the west coast of North America (Rizzo et al. 2002). Unlike most fungal cell walls, oomycete walls contain very little chitin. They primarily are composed of 1,3- $\beta$-glucan and some other $\beta$-linked glucose polymers; and, in Phytophthora spp., these $\beta$-glucans compose up to $90 \%$ of the dry weight (Bartnicki-Garcia and Wang 1983). Protein levels in the cell walls of fungi and oomy- 
cetes are comparable and are reported to range from 3 to $11 \%$ depending on the species studied (Bartnicki-Garcia and Wang 1983).

Fungal and oomycete plant pathogens secrete a variety of extracellular effector molecules to promote the infection process (Birch et al. 2006; Dean et al. 2005; Westerink et al. 2004). Recognition of effector proteins can elicit plant defense responses that ultimately result in a hypersensitivity response (HR) or programmed cell death. Several cell wall components and cell wall proteins are known to act as elicitors of plant defense responses (Cote et al. 1998; Hahn 1996; Rose et al. 2002). Therefore, understanding the pathogens' cell wall composition is expected to provide new insights into mechanisms underlying plant-pathogen interactions. The release of the complete genome sequence of two Phytophthora spp. provides the opportunity to search for genes encoding putative cell wall proteins (Tyler et al. 2006). A genome-wide inventory of secreted proteins of $P$. sojae and $P$. ramorum already revealed putative secretomes of 1,464 and 1,188 proteins, respectively (Jiang 2006), of which a subset of approximately 100 proteins contain putative GPI anchor addition sequences. This suggests that, also in Phytophthora spp., GPI modification might be a way to tether proteins to the exterior of the cell (Jiang et al. 2006; R. H. Y. Jiang and F. Govers, unpublished).

In this study, we present a detailed analysis of the cell wall composition of $P$. ramorum. First, we investigated the chemical composition of the mycelial cell walls and, second, we performed a detailed analysis of the cell wall proteome using liquid chromatography tandem mass spectrometry (LC/MS/ MS). By sequencing the peptides and exploiting the genome sequence, 17 CWPs could be identified, none of which contains a putative GPI anchor. They comprise proteins involved in polysaccharide modification, adhesion, and virulence. The identification of these CWPs provides a first foray into Phytophthora cell wall proteomics.

\section{RESULTS AND DISCUSSION}

\section{Chemical composition of the cell wall.}

In order to analyze the sugar composition of mycelial cell walls of $P$. ramorum, polysaccharides in SDS-treated cell walls of strain Pr04 were hydrolyzed using sulfuric acid and analyzed by high-performance liquid chromatography (HPLC). Glucose monomers appeared to represent $97 \pm 4 \%$ of the cell wall mass, whereas mannose, galactose, and glucosamine were below detection levels. Chitin, which was determined separately, also was below the detection level, which is consistent with the lack of detectable levels of glucosamine by HPLC and with the very high percentage of glucose in $P$. ramorum cell walls. The amount of covalently bound proteins was quantified at $1.2 \pm 0.2 \%$. These results suggest that, in addition to a small amount of protein, the cell wall is composed almost exclusively of glucan. In comparison with earlier studies on Phytophthora cell walls, the glucan levels in P. ramorum seem to be relatively high. Bartnicki-Garcia and Wang (1983) reported analyses on the cell wall composition in $P$. cinnamomi, $P$. parasitica, $P$. palmivora, $P$. heveae, and $P$. megasperma var. sojae. These analyses, based on enzymatic digestions and methylation analysis, revealed 86 to $90 \%$ glucose, 3 to $11 \%$ protein, and minor amounts of lipids and polysaccharides, including mannose and glucosamine. Although this comparison suggests that glucan levels differ between species, it is more likely that the differences are due to the methodology that was used to isolate the cell walls or to quantify the components.

BLAST analysis using sequences from ascomycetous fungi as queries revealed that homologs of genes involved in 1,3- $\beta$ glucan synthesis ( $F K S$ genes), 1,3- $\beta$-glucan modification (GAS and $B G L$ ), and 1,6- $\beta$-glucan synthesis (KRE6) are present in Phytophthora spp., whereas homologs of 1,3- $\alpha$-glucan synthase-encoding genes (MOKI/AGSI family) are absent. Interestingly, although chitin levels in the cell wall are below the detection levels, $P$. ramorum does contain clear homologs of chitin synthase and chitinase. Homologs of the CRH family, believed to mediate the covalent attachment of chitin to $1,3-\beta$ glucan in yeast, are absent.

\section{CWPs in P. ramorum.}

To identify putative CWPs of $P$. ramorum, isolated cell walls from four different $P$. ramorum strains were digested with trypsin and the solubilized peptides were analyzed by MS/MS. Obtained MS/MS data were compared with an in silico digest of the $P$. ramorum proteome using Mascot with a high confidence limit setting $(P<0.05)$. The number of peptides found for each identified protein ranged from 1 to 9 . For 10 proteins, multiple peptides were found. When only a single peptide was present, its MS/MS spectrum was verified manually and the peptide was considered to be a positive score only when it also was present in other $P$. ramorum strains. Altogether, this allowed the unambiguous identification of 17 CWPs from $P$. ramorum mycelium (Table 1). Importantly, all identified CWPs, except for one protein derived from an incomplete gene sequence, appeared to contain canonical $N$-terminal signal peptides for entry into the endoplasmic reticulum. This indicates that they are bona fide cell surface proteins, secreted via the classical secretion pathway (Table 2). BLAST searches revealed that 16 of the identified CWPs have homologs in other species and, based on the predicted functions of the homologs, they were divided into six functional categories (Table 2). Each category is discussed in more detail below.

\section{Mucins and mucin-like proteins.}

Six proteins were classified as mucins or mucin-like proteins. Mucins belong to a family of glycoproteins that are secreted or associated with the cell surface and can act as lubricants, protectants, or signal transduction mediators. Glycosylation often is found at serine and threonine residues in a variable number of tandem repeat (VNTR) regions that are flanked by nonrepetitive $N$ - and $C$-terminal domains. Mucin-like proteins are similar but lack the VNTR regions (Hicks et al. 2000; Theodoropoulos et al. 2001).

The protein encoded by gene model Pr_75613 was identified by three peptides (Table 1; Fig. 1). The mature protein is acidic and rich in proline and threonine residues (Table 2). The primary structure of the protein is depicted in Figure 1. It is predicted to start with a proline-rich extensin signature, and this is followed by two proline- and threonine-rich repeat domains. In the first repeat domain, a stretch of 45 amino acids (aa) is repeated 11 times. This 45 -aa repeat, in turn, is composed of two alternating, highly homologous repeats of 23 and 22 aa, respectively. The second repeat domain contains three nearly perfect 18 -aa repeats, two nearly perfect 11 -aa repeats, and one 8-aa imperfect repeat. Surprisingly, the $C$-terminus has a putative transmembrane (TM) region (Fig. 1). Extensin signatures are typical for a class of plant cell wall proteins collectively called extensins (Cassab 1998; Showalter 1993). These are highly glycosylated plant cell wall proteins that can make up $20 \%$ of the cell wall. Their function is to strengthen the cell wall, possibly by interacting with cell wall carbohydrates.

Eight peptides point to a protein encoded by gene model Pr_75750 (Table 1). Its length is 1,631 aa and, in the $C$-terminal half, it has two repeat domains, a proline/threonine-rich region and a TM domain (Table 2; Fig. 2). One repeat domain contains 22 imperfect repeats of 9 aa (consensus 'STTTTTTGS'), 
whereas the other contains 11 nearly perfect repeats of 14 aa (consensus 'DVxT/PTEAPTPCPTT').

Five peptides identified the proteins encoded by gene models Pr_75424 and PR_73547 (two and three, respectively) (Table 1). For both proteins, the identified peptides confirm the start of the mature protein as predicted by SignalP (Table 2). In $P$. ramorum, Pr_75424 and Pr_73547 are each other's closest homologs, with $60 \%$ identity in the first 109 aa (Fig. 3). Further downstream, homology between the two proteins is caused by a large number of repeats with the consensus sequence 'TPCPVTSLP(D/E)'. Pr_75424 has 17 of these repeats and Pr_73547 has 28 . The inter-repeat regions are variable and differ in length (Fig. 3).

Two more proteins with homology to mucins were identified. One, encoded by gene model Pr_80868, was identified by three peptides. The mature protein is acidic, consists mainly of asparagine, glycine, serine, and threonine residues, and contains a few repeats (Table 2). Of the second protein, encoded in

Table 1. Identification of cell-wall-associated proteins of Phytophthora ramorum by liquid chromatography tandem mass spectrometry ${ }^{\mathrm{a}}$

\begin{tabular}{|c|c|c|c|c|c|c|c|c|c|c|}
\hline \multirow[b]{2}{*}{ Protein ID } & \multirow[b]{2}{*}{ Residues } & \multirow[b]{2}{*}{$\begin{array}{c}\text { Ion mass } \\
(\mathbf{m} / \mathbf{z})\end{array}$} & \multirow[b]{2}{*}{$\begin{array}{l}\text { Measured } \\
\text { mass }\end{array}$} & \multirow[b]{2}{*}{ State $^{b}$} & \multirow[b]{2}{*}{ Peptide $^{c}$} & \multirow[b]{2}{*}{ Comment $^{d}$} & \multicolumn{4}{|c|}{ Mascot score in each strain } \\
\hline & & & & & & & $\begin{array}{c}\text { CBS } \\
110536\end{array}$ & $\begin{array}{c}\text { PD } \\
20023604\end{array}$ & $\begin{array}{l}\text { CBS } \\
110534\end{array}$ & $\begin{array}{c}\text { CBS } \\
101553\end{array}$ \\
\hline 53744 & $130-139$ & 486.77 & 971.53 & $2+$ & TGTPTVPATK & & Ms & Ms & 32 & Ms \\
\hline \multirow[t]{4}{*}{71633} & $73-81$ & 542.77 & $1,083.54$ & $2+$ & VDACHELIK & Cys_CAM: 76 & 72 & 68 & 58 & $\ldots$ \\
\hline & $73-81$ & 362.18 & $1,083.54$ & $3+$ & VDACHELIK & Cys_CAM: 76 & $\ldots$ & 23 & 20 & $\ldots$ \\
\hline & $82-105$ & $1,264.58$ & $2,527.2$ & $2+$ & NVQATNPPDCDLSIPTSGAVMNVK & Cys_CAM: 91 & $\ldots$ & 101 & 70 & $\ldots$ \\
\hline & $82-105$ & 843.4 & $2,527.2$ & $3+$ & NVQATNPPDCDLSIPTSGAVMNVK & Cys_CAM: 91 & 43 & 65 & 120 & $\ldots$ \\
\hline \multirow[t]{2}{*}{72319} & $48-62$ & 815.94 & $1,629.88$ & $2+$ & CKPATQISAELATLK & Cys_CAM: 48 & $\ldots$ & $\ldots$ & 45 & $\ldots$ \\
\hline & $215-227$ & 665.34 & $1,328.66$ & $2+$ & FSALVDTAGAYSK & $\ldots$ & $\ldots$ & $\ldots$ & 48 & $\ldots$ \\
\hline \multirow[t]{3}{*}{73547} & $23-30$ & 476.21 & 950.41 & $2+$ & DTDVSVCR & $\mathrm{N}$-terminal peptide & $\ldots$ & $\ldots$ & 29 & 29 \\
\hline & $23-40$ & 682.3 & $2,043.92$ & $3+$ & DTDVSVCRDATYTIADSR & $\mathrm{N}$-terminal peptide & 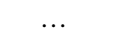 & 3 & & $\ldots$ \\
\hline & $31-40$ & 556.77 & $1,111.51$ & $2+$ & DATYTIADSR & - & 49 & 42 & 27 & $\ldots$ \\
\hline $74257 \mathrm{a}$ & $142-155$ & 737.35 & $1,472.7$ & $2+$ & ECTGNAVPVGSVQR & Cys_CAM: 143 & Ms & 54 & Ms & $\ldots$ \\
\hline \multirow[t]{6}{*}{$74257 \mathrm{~b}$} & $548-561$ & 845.42 & $1,688.82$ & $2+$ & TDIQQIGQYFSSFR & $\ldots$ & 84 & $\ldots$ & $\ldots$ & $\ldots$ \\
\hline & $643-658$ & 572.3 & $1,713.88$ & $3+$ & VKECTGNAVPVGTVQR & Cys_CAM: 646 & $\ldots$ & 11 & 29 & $\ldots$ \\
\hline & $643-658$ & 857.93 & $1,713.88$ & $2+$ & VKECTGNAVPVGTVQR & Cys_CAM: 646 & 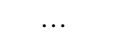 & 76 & & $\ldots$ \\
\hline & $645-658$ & 744.37 & $1,486.72$ & $2+$ & ECTGNAVPVGTVQR & Cys_CAM: 646 & 54 & 50 & 38 & $\ldots$ \\
\hline & $659-670$ & 631.29 & $1,260.57$ & $2+$ & INEWNGASGADK & $\ldots$ & & 29 & 64 & $\ldots$ \\
\hline & $774-785$ & 647.32 & $1,292.61$ & $2+$ & HFGVFNTDGTAK & & 25 & 76 & 93 & $\ldots$ \\
\hline \multirow[t]{2}{*}{75424} & $20-29$ & 601.31 & $1,200.62$ & $2+$ & LEDLPVSLCR & $\mathrm{N}$-terminal peptide & 67 & 50 & & $\ldots$ \\
\hline & $30-39$ & 541.25 & $1,080.48$ & $2+$ & DATYNSPASR & $\ldots$ & 18 & $\ldots$ & 42 & 39 \\
\hline \multirow[t]{3}{*}{75613} & $123-136$ & 759.88 & $1,517.72$ & $2+$ & DCIDTLPSWAGVGK & Cys_CAM: 124 & 46 & $\ldots$ & & $\ldots$ \\
\hline & $137-147$ & 640.27 & $1,278.52$ & $2+$ & CEAPVDAMCAR & $\begin{array}{l}\text { Cys_CAM: } 137, \\
145\end{array}$ & & & 44 & $\cdots$ \\
\hline & $148-161$ & 732.85 & $1,463.69$ & $2+$ & VASGAWGCVFGEPK & Cys_CAM: 155 & 74 & 89 & 93 & $\ldots$ \\
\hline \multirow[t]{8}{*}{75750} & $113-122$ & 620.89 & $1,239.69$ & $2+$ & LLLAYESYLR & & 49 & & & $\ldots$ \\
\hline & $376-390$ & 899.4 & $1,796.79$ & $2+$ & QQILSNNDMCTGFNR & Cys_CAM: 385 & 92 & 85 & 89 & $\ldots$ \\
\hline & $391-405$ & 756.91 & $1,511.8$ & $2+$ & AFAASYTTLNAAAIK & $\ldots$ & 86 & 71 & 84 & $\ldots$ \\
\hline & $452-462$ & 553.81 & $1,105.6$ & $2+$ & STVTSGQLVSK & $\ldots$ & 61 & 30 & 42 & $\ldots$ \\
\hline & $634-642$ & 478.8 & 955.58 & $2+$ & SGLLQLAVR & $\ldots$ & 77 & 56 & 43 & $\ldots$ \\
\hline & $653-660$ & 440.75 & 879.48 & $2+$ & FASSTVIR & $\ldots$ & 49 & $\ldots$ & 51 & $\ldots$ \\
\hline & $673-678$ & 390.24 & 778.47 & $2+$ & KVTYIR & $\ldots$ & $\ldots$ & $\ldots$ & $\ldots$ & 18 \\
\hline & 1196-1208 & 704.87 & $1,407.66$ & $2+$ & TGAWGCVFGTPQK & Cys_CAM: 1201 & 85 & $\ldots$ & $\ldots$ & \\
\hline \multicolumn{11}{|c|}{79075 or } \\
\hline \multirow{2}{*}{$\begin{array}{l}79079 \\
79145\end{array}$} & $64-73$ & 602.79 & $1,203.53$ & $2+$ & WSDDGQNVQR & $\ldots$ & $\ldots$ & 36 & $\cdots$ & 52 \\
\hline & $273-286$ & 773.32 & $1,544.66$ & $2+$ & VSDKACSAACTTQF & $\begin{array}{l}\text { Cys_CAM: } 278, \\
282\end{array}$ & $\ldots$ & 60 & Ms & $\cdots$ \\
\hline 80516 & $387-402$ & 812.33 & $1,622.68$ & $2+$ & SGGSAPSEGCSVVCNR & $\begin{array}{l}\text { Cys_CAM: } 396, \\
400\end{array}$ & $\ldots$ & Ms & 16 & 24 \\
\hline 80868 & $24-41$ & 946.97 & $1,891.92$ & $2+$ & DTPVSVLGDATYSIPDSR & N-terminal peptide & $\ldots$ & 82 & 114 & $\ldots$ \\
\hline & $42-69$ & 934.77 & $2,801.33$ & $3+$ & $\begin{array}{l}\text { GVICIGAGAAPTGTACPLKGEVA } \\
\text { SDNCR }\end{array}$ & $\begin{array}{l}\text { Cys_CAM: } 45,57 \text {, } \\
68\end{array}$ & & & 16 & \\
\hline & $77-92$ & 902.89 & $1,803.78$ & $2+$ & DGECVAPEDAECVVVR & Cys_CAM: 80,88 & $\begin{array}{l}\cdots \\
\cdots\end{array}$ & 33 & 41 & $\cdots$ \\
\hline 83136 & $97-104$ & 467.73 & 933.46 & $2+$ & DATCQVIK & Cys_CAM: 100 & 20 & $\ldots$ & 54 & 46 \\
\hline 83169 & $157-175$ & 938.93 & $1,875.89$ & $2+$ & TGTTVSQTSTSTSTSTTTK & $\ldots$ & $\ldots$ & & 27 & 25 \\
\hline 83680 & $24-31$ & 468.25 & 934.49 & $2+$ & SNVNFINK & $\mathrm{N}$-terminal peptide & $\ldots$ & 50 & 29 & $\ldots$ \\
\hline & $115-126$ & 666.86 & $1,331.69$ & $2+$ & KGFNVPMSVEPK & $\ldots$ & $\ldots$ & & 64 & $\ldots$ \\
\hline & $116-126$ & 602.8 & $1,203.6$ & $2+$ & GFNVPMSVEPK & $\ldots$ & $\ldots$ & 47 & $\ldots$ & $\ldots$ \\
\hline & $238-249$ & 574.32 & $1,146.62$ & $2+$ & QGTVSTGLGTVK & $\ldots$ & $\ldots$ & 27 & 16 & $\ldots$ \\
\hline & $269-277$ & 490.74 & 979.46 & $2+$ & VTDLGSCTK & Cys_CAM: 275 & $\ldots$ & $\ldots$ & 46 & 50 \\
\hline & $327-340$ & 798.87 & $1,595.72$ & $2+$ & QDGTTDNLVFMNNK & $\ldots$ & $\cdots$ & 119 & 110 & \\
\hline & $348-361$ & 678.81 & $1,355.62$ & $2+$ & NAHGPQGFASADGK & $\ldots$ & $\ldots$ & 33 & $\ldots$ & 75 \\
\hline & $425-432$ & 461.27 & 920.53 & $2+$ & KAFVTEVK & $\ldots$ & $\ldots$ & $\ldots$ & 14 & $\ldots$ \\
\hline & $426-432$ & 397.23 & 792.44 & $2+$ & AFVTEVK & $\ldots$ & $\ldots$ & 33 & 15 & $\ldots$ \\
\hline 87858 & $678-686$ & 479.78 & 957.55 & $2+$ & SNAEIALLK & $\ldots$ & $\ldots$ & $\ldots$ & 30 & $\ldots$ \\
\hline & $734-743$ & 518.77 & $1,035.52$ & $2+$ & AAADADVLYK & $\ldots$ & $\cdots$ & $\cdots$ & 22 & $\ldots$ \\
\hline
\end{tabular}

a Abbreviations: CBS = Centraalbureau voor Schimmelcultures, PD = Plantenziektekundige Dienst, and Ms = manual inspection of mass spectrometry spectra indicated that the peptide is present but not selected for fragmentation.

${ }^{\mathrm{b}}$ Charge state.

${ }^{\mathrm{c}}$ Identified peptide sequence.

${ }^{\mathrm{d}}$ Modification or comment. 
gene model Pr_83136, only one peptide was identified; however, this peptide was found in cell wall preparations of three $P$. ramorum strains. The protein is rich in alanine and glycine residues (Table 2 ). The mature protein has no obvious repeats and, therefore, is classified as a mucin-like protein.

Five of the mucin or mucin-like proteins identified in this study are most homologous to a mucin-like protein in the nematode Heterodera glycines (Table 2) and all six have homology to the cyst germination-specific acidic repeat (Car) proteins in P. infestans (Gornhardt et al. 2000), based on a motif spanning 67 to 69 aa (Fig. 4). All mucin or mucin-like proteins contain multiple repeats of the sequence "TPxP". The lowest number $(n=6)$ was found in Pr_83136 and the highest $(n=45)$ in $\operatorname{Pr}_{-} 75613$. These repeats are part of the repeats indicated in Figure 1 (box III) and Figure 3. This suggests that the mucin or mucin-like proteins have a common ancestor but have diverged over time.

In five of the six $P$. ramorum CWPs categorized as mucins, we found repeats that are relatively rich in proline, threonine, and serine (Table 2), and they resemble the VNTR-containing mucins described in other species (Hicks et al. 2000; Theodoropoulos et al. 2001). The VNTR-containing mucins are glycosylated through $O$-linked $N$-acetylgalactosamine to serine and threonine residues in their VNTR regions. As yet, there is no experimental evidence for $O$-glycosylation in Phytophthora spp. For the $P$. infestans mucin Car90, Gornhardt and associates (2000) failed to get clear-cut evidence for $O$-glycosyla- tion with either a glycan-detection kit or by enzymatic deglycosylation. In $P$. ramorum, the mannose level in cell walls is below threshold values, and the amount of glucose plus protein accounts for nearly the entire cell wall mass; therefore, one may assume that $O$-glycosylation is either sparse or even absent in Phytophthora spp. Consistent with this, obvious orthologs of genes that are involved in $O$ - or $N$-mannosylation in ascomycetous fungi such as the PMT1 family, MNT1 and MNT2, $O C H 1$, and MNN4 (Bates et al. 2006; Hobson et al. 2004; Munro et al. 2005; Prill et al. 2005) are absent in P. ramorum. Alternatively, $O$-linked carbohydrate side chains may consist of glucose. Two of the identified $P$. ramorum mucins (Pr_75613 and Pr_75750) have putative TM domains close to their $C$ termini, which is rather surprising. Assuming that both gene models are correct, these TM domains are unlikely to serve as GPI-addition signals. Therefore, these proteins are expected to be integrated into the plasma membrane with the large $N$-terminal part of the protein facing the cell wall. Consistent with this, the presence of TM domains in cell wall proteins is unprecedented in fungi. Immediately upstream of the TM domains, both proteins contain stretches of consecutive glutamine residues. Possibly, these regions may serve as acceptor sites for transglutaminases and may cause the proteins to be covalently coupled to cell wall proteins, explaining their presence in cell wall extracts. There are mucins in other species that have TM regions but there is no indication that these are associated with the cell wall (Gipson 2004; Hicks et al. 2000).

Table 2. Characteristics of identified Phytophthora ramorum cell wall proteins ${ }^{\mathrm{a}}$

\begin{tabular}{|c|c|c|c|c|c|c|c|c|}
\hline Function, ID $^{\mathbf{b}}$ & $\begin{array}{l}\text { Size of } \\
\text { MP (aa) }\end{array}$ & $\begin{array}{c}\text { Peptide } \\
(\text { aa) }\end{array}$ & $\begin{array}{l}\text { pI of } \\
\text { MP }\end{array}$ & $\begin{array}{c}\text { Amino acids with } \\
\geq 10 \% \text { frequency }(\%)\end{array}$ & $\operatorname{Reps}^{\mathrm{d}}$ & Best BlastP match & $\begin{array}{c}\text { GenBank } \\
\text { no. }\end{array}$ & E value \\
\hline \multicolumn{9}{|l|}{ Mucin } \\
\hline 73547 & 646 & 22 & 3.44 & $\mathrm{~T}(27), \mathrm{P}(18), \mathrm{S}(11)$ & Yes & $\begin{array}{l}\text { Mucin-like protein } \\
\text { (Heterodera glycines) }\end{array}$ & AAC62109.1 & $3 \mathrm{E}-37$ \\
\hline 75424 & 324 & 19 & 3.49 & $\mathrm{~T}(22), \mathrm{P}(21), \mathrm{A}(10)$ & Yes & Mucin-like protein (H. glycines) & AAC62109.1 & $2 \mathrm{E}-34$ \\
\hline 75613 & 804 & 18 & 3.72 & $\mathrm{P}(24), \mathrm{T}(20)$ & Yes & $\begin{array}{l}\text { Mucin 2, intestinal/tracheal } \\
\text { (Methanospirillum hungatei JF-1) }\end{array}$ & YP_502753.1 & $1 \mathrm{E}-59$ \\
\hline 75750 & 1,612 & 19 & 3.44 & $\mathrm{~T}(27), \mathrm{P}(18), \mathrm{S}(11)$ & Yes & Mucin-like protein $(H$. glycines $)$ & AAC62109.1 & $6 \mathrm{E}-25$ \\
\hline 80868 & 781 & 23 & 3.83 & $\begin{array}{l}\mathrm{G}(12), \mathrm{S}(12), \mathrm{T}(12), \\
\mathrm{D}(11)\end{array}$ & Yes & Mucin-like protein (H. glycines) & AAC62109.1 & 7E-20 \\
\hline $\begin{array}{l}83136 \\
\text { Glucanases }\end{array}$ & 275 & 19 & 5.28 & G (19), A (11) & $\ldots$ & Mucin-like protein (H. glycines) & AAC62109.1 & $2 \mathrm{E}-26$ \\
\hline $74257 \mathrm{a}$ & 388 & 23 & 3.57 & $\mathrm{~T}(18), \mathrm{S}(13), \mathrm{A}(11)$ & $\ldots$ & $\begin{array}{l}\text { Unnamed protein product } \\
\text { (Debaryomyces hansenii CBS767) }\end{array}$ & CAG88512 & $3 \mathrm{E}-12$ \\
\hline $74257 b$ & 390 & 23 & 4.19 & $\mathrm{~T}(13), \mathrm{A}(11)$ & $\ldots$ & $\begin{array}{l}\text { Glycosyl hydrolase, family } 17 \\
\text { (uncultured bacterium } 443 \text { ) }\end{array}$ & AAR37824.1 & $7 \mathrm{E}-12$ \\
\hline 72319 & 372 & 23 & 3.93 & A (17), T (10) & $\ldots$ & $\begin{array}{l}\text { Putative endo-1,3-beta-glucanase } \\
\text { (P. infestans })\end{array}$ & AAM18482.1 & $4 \mathrm{E}-120$ \\
\hline $79075 / 79079$ & 359 & 19 & 7.73 & $\mathrm{G}(11)$ & & Unknown protein $(P$. sojae $)$ & AAO24650.1 & $6 \mathrm{E}-23$ \\
\hline 83680 & 532 & 23 & 4.84 & $\mathrm{G}(11)$ & $\ldots$ & $\begin{array}{l}\text { Secretory protein OPEL } \\
(P . \text { parasitica })\end{array}$ & AAP85258.1 & 0 \\
\hline Transglutaminases & & & & & & & & \\
\hline 53744 & 518 & 26 & 4.6 & $\mathrm{~T}(12)$ & $\ldots$ & $\begin{array}{l}\text { Transglutaminase elicitor M81C } \\
(P . \text { infestans })\end{array}$ & AAP70477.1 & 0 \\
\hline 83169 & 749 & 26 & 4.35 & $\mathrm{~T}(17), \mathrm{S}(15), \mathrm{A}(11)$ & $\ldots$ & $\begin{array}{l}\text { Transglutaminase elicitor M81C } \\
(P . \text { infestans })\end{array}$ & AAP70477.1 & $3 \mathrm{E}-163$ \\
\hline $\begin{array}{l}\text { Annexin-like protein } \\
87858\end{array}$ & $773+$ & $?$ & 4.57 & $\begin{array}{l}\mathrm{T}(13), \mathrm{S}(12), \mathrm{A}(11), \\
\mathrm{E}(11)\end{array}$ & Yes & Annexin A13 (Homo sapiens) & CAG46637.1 & $4 \mathrm{E}-18$ \\
\hline $\begin{array}{l}\text { Elicitin protein } \\
71633 \\
\text { Kazal protein }\end{array}$ & 172 & 20 & 3.9 & A (24), T (19) & Yes & Elicitin protein RAM5 (P. ramorum) & ABB55988.1 & $3 \mathrm{E}-52$ \\
\hline 79145 & 268 & 18 & 3.73 & S (16), G (10) & $\ldots$ & $\begin{array}{l}\text { Predicted: similar to agrin, partial } \\
\text { (Strongylocentrotus purpuratus) }\end{array}$ & XP_782290.1 & $2 \mathrm{E}-39$ \\
\hline $\begin{array}{l}\text { Unknown } \\
80516\end{array}$ & 571 & 19 & 4.48 & $\mathrm{~T}(14), \mathrm{S}(13), \mathrm{A}(11)$ & $\ldots$ & No significant hit & $\ldots$ & $\ldots$ \\
\hline
\end{tabular}

\footnotetext{
a Abbreviations: $\mathrm{MP}=$ mature protein, $\mathrm{aa}=$ amino acids, and $\mathrm{pI}=$ isoelectric point

${ }^{b}$ Predicted function and protein identification.

${ }^{\mathrm{c}}$ Signal peptide size.

${ }^{\mathrm{d}}$ Repeats were determined by rapid automatic detection and alignment of repeats.

e This gene lacks the $5^{\prime}$ region.
} 


\section{Glycoside hydrolases.}

Among the identified CWPs, there are five putative glycoside hydrolases. Glycoside hydrolases are ubiquitous enzymes that hydrolyze the glycoside bond between two or more carbohydrates or between a carbohydrate and a no carbohydrate moiety and may have transglycosidic activity (Henrissat and Bairoch 1996).

Six peptides were identified from a protein encoded by gene model Pr_74257. Two of the peptides (14 aa long) are nearly identical, with only 1 aa difference. They are located in two different regions of the predicted protein, which prompted us to analyze the current gene model in more detail. This revealed that, in fact, Pr_74257 represents two genes that are highly homologous and encode putative 1,3- $\beta$-endoglucanase precursors (now designated as Pr_74257a and Pr_74257b) (Fig. 5). SignalP analysis validated that both genes encode a protein with a signal peptide of 23 aa. Directly adjacent to Pr_74257a and Pr_74257b are two additional 1,3- $\beta$-endoglucanase genes ( $\operatorname{Pr}_{-} 74255$ and Pr_74256) (Fig. 5). The homology of the proteins in this gene cluster is restricted to their $N$-terminal half, in a region directly

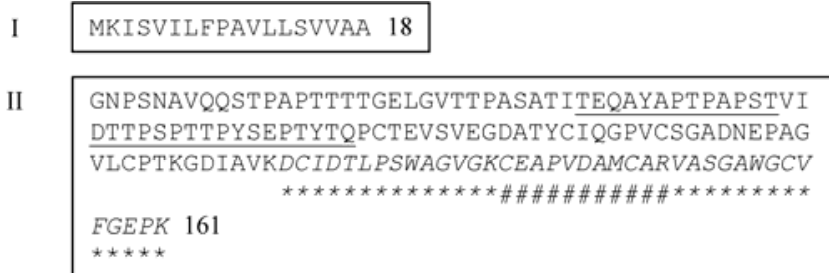

III \begin{tabular}{|l|r|}
\hline VGDYITPAPTTPETYEQSTPDTY & EQPTPASTTPYRDVPSPTPTW \\
VDISPPPATPCPSKDVPPPTPTY & GVTPAPTTPCPSEEVPSPTPTW \\
VEITPAPTTPGPYEEAPSPTPTY & GVTPAPTTPCPSEEVPSPTPTW \\
VEITPAPTTPGPYEEAPSPTPTY & GVTPAPTTPCPSEEVPSPTPTW \\
VEITPAPTTPGPYEEAPSPTPTY & GMTPAPTTPCPSEEVPSPTPTW \\
VEITPAPTTPGPYEEAPSPTPTY & GMTPSPTTPCPSEEVPSTPTW \\
VEITPAPTTPGPYEEAPSPTPTY & GVTPAPTTPCPSEEVPSPTPTW \\
VEITPAPTTPGPYEEAPSPTPTY & GVTPAPTTPCPSEEVPSPTPTW \\
VEITPAPTTPGPYEEAPSPTPTY & GVTPAPTTPCPLEEVPSTPTW \\
VEITPAPTTPGPYEEAPSPTPTY & GVTPAPTTPCPSEEVPSTPTW \\
VEITPAPTTPGPYEEAPSPTPTY & GMTPSPTT 641
\end{tabular}

IV

$$
\begin{array}{r}
\text { PYPSTLVPPETTQPPTVA } \\
\text { PYPSTPIPPETTQPPTVA } \\
\text { PYPSTPVPPETTQPPTVA } \\
\text { PYSTTQPPTVA } \\
\text { PYSTTQPPKST } \\
\text { PSVTPATP } 725
\end{array}
$$

$\mathrm{V}$

\section{EQQQQDQTQNGEKQQVQDQNQQQQQTDSSTSQQITTKTNDASDNVN TASAIGIGGVAAIVAGVGAILAIAGFAAY $Q R R Q N A D R T S L H V Y Q G H$ VATPV* 822}

Fig. 1. Pr_75613 encodes a cell wall protein with mucin characteristics. The primary structure of Pr_75613 contains a predicted $N$-terminal signal peptide (I), a proline-rich extensin signature (in II and III; underlined), two repeat domains (III and IV), and a $C$-terminus with a transmembrane domain (bold) (V). Peptides identified by liquid chromatography tandem mass spectrometry are indicated by $*$ and \#. downstream of the signal peptides that specifies the catalytic domain and is shared by all copies. The closest $S$. cerevisiae homolog is Scw10p, which belongs to glycoside hydrolase $(\mathrm{GH})$ family 17 . Members of this family have been found in various fungi as well as plants (Henrissat 1991; Henrissat and Bairoch 1993, 1996). Scw10p has no consensus sequence for GPI modification and recently has been identified as a covalently bound CWP that is linked through an alkali-sensitive linkage (Yin et al. 2005).

Two peptides identified the protein encoded by $\mathrm{Pr}_{-} 72319$, which also is annotated as an endo-1,3- $\beta$-glucanase of GH 17 (Table 1). The highest level of homology was found with its $P$. sojae ortholog Ps_141908 (82\% similar, 75\% identical) and with PiENDO1 of $P$. infestans ( $81 \%$ similar; $73 \%$ identical) (McLeod et al. 2003). Outside the genus Phytophthora, the closest homolog was a putative endo-1,3- $\beta$-glucanase (expressed sequence tag [EST] AAY53769) from the oomycete fish pathogen Saprolegnia parasitica (Torto-Alalibo et al. 2005) (Table 2 ). The closest homolog in baker's yeast is Bgl2p, which is associated with cell walls but, unlike the proteins identified in our study, is not resistant to extraction with hot SDS (Klebl and Tanner 1989).

Based on the current genome sequence assembly, one peptide could be assigned to two genes, Pr_79075 and Pr_79079, which are $100 \%$ identical (Table 1). Due to the absence of sequence information in the flanking untranscribed regions, we cannot determine if they are gene duplications or assembly artifacts. The encoded protein has a signal peptide of 19 aa and is relatively cysteine rich. The latter is a common feature of elicitor proteins (Jiang et al. 2006). The protein has two cellulose-binding do-

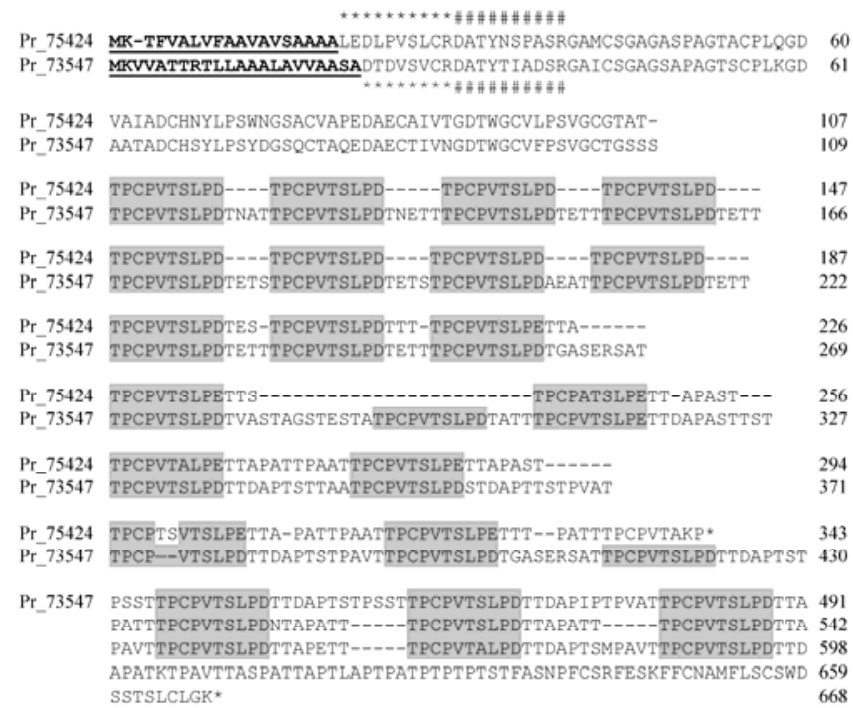

Fig. 3. Pr_73547 and Pr_75424 encode two homologous cell wall proteins with mucin characteristics. Pairwise sequence alignment of the proteins encoded by Pr_73547 and Pr_75424. In the mucin proteins the signal peptides (bold and underlined), and the repeat sequences (shaded) are indicated. Identified peptides are indicated by * and \#.

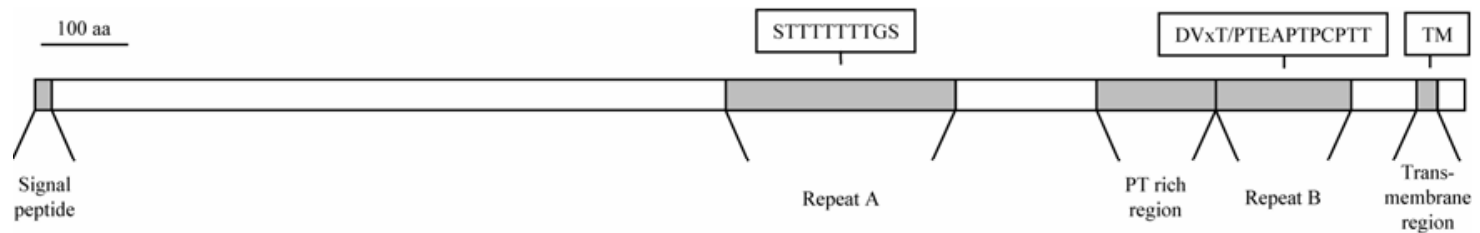

Fig. 2. Modular structure of the putative mucin cell wall protein encoded by Pr_75750. The putative mucin encoded by Pr_75750 is 1,631 amino acids (aa) long and has an $\mathrm{N}$-terminal signal peptide, a proline/threonine-rich region, a putative transmembrane region, and two repeat domains, A and B. A has 22 imperfect repeats of 9 aa and $\mathrm{B}$ has 11 nearly perfect repeats of 14 aa. 
mains and weak homology with endo-1,4- $\beta$-D-glucanases (cellobiohydrolases; GH 6; E value $>0.64$ ) that degrade cellulose by splitting off cellobiose (glucose dimer) molecules. Several homologous proteins are present in $P$. ramorum and $P$. sojae. One of the $P$. sojae homologs, encoded by EST 1-7c-MY, was selected as a putative elicitor based on its cysteine-rich features and tested for necrosis-inducing activity on Nicotiana benthamiana using Potato virus $X$ (PVX) vectors for in planta expression. Expression of 1-7c-MY was found to affect the typical mosaic lesions, suggesting that it interfered with viral replication or spreading (Qutob et al. 2002).

Nine tryptic peptides identified the protein encoded by Pr_83680 (Tables 1 and 2). BLAST analysis revealed homology with the secretory protein OPEL from $P$. parasitica $(79 \%$ similar; $71 \%$ identical) that was isolated as a putative polygalacturonase (R. F. Liou, personal communication). Homology to other proteins was restricted to two regions. The first 150 aa have homology with thaumatins, which are monomeric plant proteins with disulfide bonds and are composed of a signal peptide and a thaumatin domain. Some thaumatins have been shown to possess polymeric 1,3- $\beta$-glucanase activity (Barre et al. 2000; Grenier et al. 1999; Menu-Bouaouiche et al. 2003; Sakamoto et al. 2006). They do not belong to any classified glycoside hydrolase family (Henrissat 1991; Henrissat and Bairoch 1993, 1996). In Pr_83680, at least 5 of the 17 cysteine residues are conserved when compared with thaumatins. The $C$-terminal part has some homology with non-plant-derived proteins and its closest homolog in Saccharomyces cerevisiae is Tos $1 \mathrm{p}$ (23\% identity, $35 \%$ similarity). Tos $1 \mathrm{p}$ is covalently bound to the yeast cell through a mild alkali-sensitive linkage and is not GPI modified (Yin et al. 2005). Interestingly, yeast mutants lacking Tos $1 \mathrm{p}$ are highly resistant to the 1,3- $\beta$-glucandegrading enzyme Quantazyme, underlining its importance in cell wall construction (Yin et al. 2005).

The identification of five CWPs representing various classes of glycoside hydrolases is in line with results obtained from $S$. cerevisiae and $C$. albicans, where various glycoside hydrolase representatives also were found to be located in the cell wall (De Groot et al. 2004, 2005; Yin et al. 2005). Glycoside hydrolases have been proposed to be involved in cell wall expansion during growth, cell-cell fusion during mating, cell division, and biofilm formation (De Groot et al. 2005; Simmons 1994). Glycoside hydrolases in Phytophthora spp. could be involved in similar processes but also might be important for plant-pathogen interactions (McLeod et al. 2003).

\section{Transglutaminases.}

Two CWPs were identified that have homology with transglutaminases (Table 2). They belong to a family of enzymes that form covalent bonds between free amino groups (e.g., peptide-bound lysine residues and gamma-carboxamide groups of peptide-bound glutamines). They can form extensively crosslinked protein polymers.

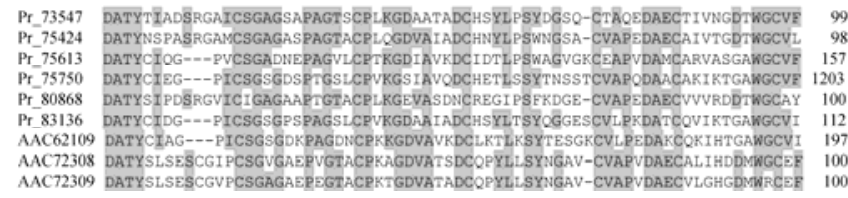

Fig. 4. Cell-wall-localized mucin(-like) proteins contain conserved motifs. Multiple sequence alignment of the six identified mucin(-like) proteins, the cyst germination-specific acidic repeat (Car) proteins in Phytophthora infestans (AAC72308 and AAC72309), and the mucin-like protein from Heterodera glycines (AAC62109). Amino acids that are identical in the majority of the proteins are shaded. Numbers indicate the positions of the last amino acids of the presented sequences in the individual proteins.
The identified proteins are encoded by gene models Pr_53744 and Pr_83169 (Tables 1 and 2). Both genes reside on the same scaffold, approximately $20 \mathrm{~kb}$ apart, with additional transglutaminase genes in the vicinity (not shown). A multigene transglutaminase family has been identified previously in several Phytophthora spp. (Brunner et al. 2002; Fabritius and Judelson 2003) and, for one of them, transglutaminase activity was shown (GP42) (Brunner et al. 2002). Pr_53744 shows strong similarity with $P$. infestans M81C (76\% identity; $86 \%$ similarity), a member of the transglutaminase elicitor-like family with structural similarity to the mating-induced glycoprotein M81 (Fabritius et al. 2002). Almost all M81-related proteins in P. infestans possess a Pep-13 peptide fragment. This peptide with the sequence 'VWNQPVRGFKVYE' was first identified in an abundant cell wall glycoprotein elicitor isolated from $P$. sojae (Nürnberger et al. 1994; Parker et al. 1991; Sacks et al. 1995) and is a so-called pathogen-associated molecular pattern (PAMP) that induces defense responses in plants. Within Pep-13, the same amino acids are indispensable for both transglutaminase activity and defenseeliciting activity. Pep-13 is fully conserved in the two cell-wallderived transglutaminases in $P$. ramorum. Compared with Pr_53744, Pr_83169 has a 70-aa insertion following the first 150 aa, and a long extended $C$-terminal region that does not contain any typical features or known domains. Pr_83169 has homology with other transglutaminases in $P$. infestans and $P$. sojae.

The Phytophthora transglutaminases form a separate group and are structurally unrelated to other transglutaminases found in many eukaryotes, bacteria, and archaea (Brunner et al. 2002; Makarova et al. 1999). Many of the microbial transglutaminases have protease activity, probably reflecting the ancestral origin of the superfamily (Makarova et al. 1999). Therefore, the Phytophthora transglutaminases might have a role as either proteases or transglutaminases. The latter may result in cell wall strengthening, connecting the plasma membrane to the cell wall by cross-linking proteins, or in cell-cell adhesion.

\section{Annexin-like protein.}

Two peptides identified the protein encoded in gene model Pr_87858 (Table 1). This gene is located on a small scaffold which lacks the 5 ' region of the gene. Consequently, the $\mathrm{N}$-terminal region of the protein, specifying the start codon and the signal peptide for secretion, is missing. Unfortunately, its closest homolog in P. sojae (gene model Ps_145567) also is located on a small scaffold and seems to be incomplete as well (not shown). Assembly of the P. ramorum trace files (available at the National Center for Biotechnology Information [NCBI]) is compromised by the presence of an in-frame direct 486-bp repeat sequence, present in over 50 trace files $\left(E\right.$ value $<\mathrm{e}^{-107}$ ). The current model has 1.5 times this repeat $\left(5^{\prime}\right)$ and the encoded protein is rich in threonine and glutamate residues. In at least one trace file (gnl|ti|324361359), an in-frame start codon was detected that gave rise to a signal peptide of 19 aa (probability is 0.980). The $C$-terminus of Pr_87858 contains a putative annexin

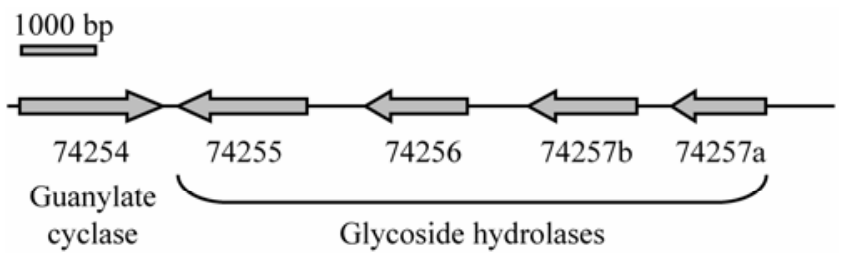

Fig. 5. Two genes encoding cell-wall-localized glycoside hydrolases of Phytophthora ramorum are part of a glycoside hydrolase gene cluster on scaffold 7. The presented $11-\mathrm{kb}$ region contains a guanylate cyclase gene (Pr_74254) and four glycoside hydrolases genes, of which Pr_74257a and Pr_74257b encode cell wall proteins. The $7-\mathrm{kb}$ downstream region of Pr_74257a contains no putative exons or gene models. 
domain and has homology with ANXA13 of Homo sapiens (Table 2) and its homologs in Gallus gallus and Rattus norvegicus. The annexin domain contains the characteristic type 2 calcium binding motif GxGT-(38 residues)-E (Moss and Morgan 2004). Annexins originally were identified as calcium-dependent phospholipid-binding proteins and are diverse in gene and protein structure. Most of them have variable amino-terminal domains (Moss and Morgan 2004) and at least two of them (annexin A1 and A2) are localized at cell surfaces (Brownstein et al. 2004; Solito et al. 1994). The identification of this protein in SDStreated cell walls implies that, in Phytophthora spp., annexins may have adapted to the requirements imposed by their hosts, resulting in cell wall localization.

\section{Elicitin protein.}

One peptide specified gene model Pr_71633 (Table 1) that previously was annotated as the elicitin RAM5 (Jiang et al. 2006). Elicitins are extracellular elicitor proteins that cause an $\mathrm{HR}$ in tobacco. Elicitins (ELIs) and elicitin-like proteins (ELLs) are characterized by an elicitin domain with six cysteine residues which have a clade-specific spacing and form three disulfide bonds involved in stabilizing the protein (Boissy et al. 1996; Fefeu et al. 1997; Jiang et al. 2006). ELIs and ELLs were shown to be unique to Phytophthora and Pythium spp. and belong to the most highly conserved and complex protein families in Phytophthora (Jiang et al. 2006). The canonical elicitins that form the ELI-1 clade consist solely of a signal peptide and an elicitin domain, and the mature ELI-1 proteins are soluble and have a globular structure. The majority of the ELIs and ELLs in the other clades have extended $C$-terminal domains with biased amino acid compositions and often are composed of repeats (Jiang et al. 2006). Their structure resembled the "lollipop on a stick" structure found in numerous surface and cell-wall-associated proteins (Jentoft 1990). RAM5 is classified as an ELI-4 elicitin (Jiang et al. 2006). The proteins in this clade are characterized by an elicitin domain with conserved cysteine spacing (C-23-C-23-C-4-C-14-C-23-C) and a $C$-terminus that possesses large quantities of threonine, serine, and proline residues. RAM5 has a $C$-terminal domain of 74 aa, 27 of which are threonine or serine, and seven TTA repeats (Jiang et al. 2006).

\section{Kazal-like protein.}

Pr_79145 was identified by a single peptide (Table 1). The

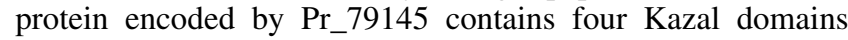
(Fig. 6A) and has homology to Kazal-type protease inhibitors.

\section{A}

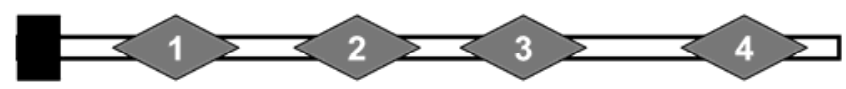

\section{B}

PrKazal-1 CSYACPDVYVPCGSDGVTY PNECSLNLENCE SQE-QVTQVSDGEC PsKazal-1 CPSMCPALHA.PVCGSDGVTYSNACRL SVANCNSQSGAITQVHDGAC PrKazal-2 CSEVCIMIYQPVCGSDGVTYGNDCILGIAQCKSGG-AITQVSDGQC Ps Kazal-2 CSKACTKIYM PVCGSDGVTYGNDCMF GVAQCKSGG-TITKVSDGQC PrKazal-3 CPEVCIEIYKPVCGSDGVTYANSCE LGIAACKNP--SITQASDGAC Ps Kazal-3 CPDECIEIWK PVCGSDGVTY ANSCF LGVATCKDP--SVTQASDGAC PrKazal-4 CPDVCYTLYAPVCGSDGVTYGNECELEVASCNHPELHITKVSDKAC PsKazal-4 CPEVCTAIYS PVCGSDGVTYGNECELGVASCKNPKQNI KKVSDGAC

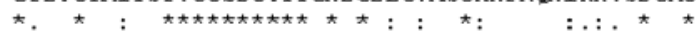

Fig. 6. Pr_79145 encodes a putative Kazal-like protease inhibitor. A, Domain organization of the Kazal type cell wall protein encoded by Pr_79145. The $N$-terminal signal peptide (black box) and four Kazal domains (gray diamonds) are indicated. B, Alignment of the Kazal domains from Phytophthora ramorum Pr_79145 (PrKazal 1 to 4) and P. sojae Ps_143590 (PsKazal 1 to 4 ).
Proteases and protease inhibitors are integral components of the plant defense response and the counter defense by pathogens (Xia 2004). Typical Kazal domains contain well-conserved amino acid sequences with cysteines forming three disulfide bridges. In oomycetes, Kazal-like proteins form a diverse family of at least 35 members, including the Kazal-like serine protease inhibitors EPI1 and EPI10 that have been identified in $P$. infestans (Tian et al. 2004). EPI1 and EPI10 inhibit the pathogenesis-related subtilisin-like serine protease P69B in tomato that is thought to function in defense (Tian et al. 2004, 2005). Pr_79145 has high homology with EPI10 and with a $P$. sojae Kazal-like protein encoded in gene model Ps_143590. Alignment of the Kazal domains in Pr_79145 and Ps_143590 is shown in Figure 6B.

\section{Unknown protein.}

The protein encoded by the single-exon gene model Pr_80516 was identified by one peptide fragment found in two strains (CBS 110534 and CBS 101553) (Table 1). With BLASTP (E value 0.5 or higher), no homologs of this protein were found outside the Phytophthora genus (Table 2). Based on the $P$. ramorum genome sequence, it is a member of a multigene family with two close paralogs directly adjacent to the gene model (Pr_80515 and Pr_80517) and two more distinct homologs elsewhere in the genome. Pr_80515, Pr_80516, and Pr_80517 are nearly identical (98\%, residues 1 to 378$)$ in their $N$-terminal regions. Compared with its paralogs, $\operatorname{Pr} \_80516$ has a $C$-terminal extension (455 to 590) with a high content of alanine, proline, serine, and threonine (adding up to 84\%). The central part of the protein has a relatively high number of cysteines (13 of 89 aa), suggesting a structural role in protein folding.

\section{Linkage of Phytophthora CWPs.}

To determine the type of linkages between the identified proteins and the cell wall network, we exploited knowledge that is available on fungal CWPs. In fungi, two types of covalent linkages between proteins and cell wall polysaccharides have been described (De Groot et al. 2005). One is a mild alkali-sensitive linkage to $1,3-\beta$-glucan. The second, which occurs more widely, is a covalent linkage to 1,6- $\beta$-glucan which takes place after GPI modification (Kapteyn et al. 1996; Kollár et al. 1997). In various sequenced fungi, in silico analyses have predicted the presence of large sets of GPI proteins (De Groot et al. 2003; Eisenhaber et al. 2004). GPI proteins are present as plasma membrane-bound proteins in many eukaryotic organisms (Sharom and Lehto 2002). In fungi and possibly other organisms with extracellular cell wall matrices, membrane-bound GPI proteins may be processed further and covalently attached to the cell wall. In S. cerevisiae and C. albicans, proteomic analysis identified 10 to 15 GPI CWPs representing the majority of the covalently bound CWPs (De Groot et al. 2004; Yin et al. 2005).

In silico analysis of the $P$. ramorum genome has indicated that $P$. ramorum contains 1,188 putative secretory proteins (Jiang 2006), among which are approximately 100 predicted GPI proteins (Jiang et al. 2006). However, none of the identified proteins presented in this article have predicted motifs for GPI anchoring at their $C$-termini, suggesting that GPI proteins of $P$. ramorum, in contrast to various yeast GPI proteins, are retained at the plasma membrane. At this point, we can only speculate why, in $P$. ramorum, GPI proteins are not or rarely bound to the cell wall. For example, the cell wall may lack 1,6$\beta$-glucan or other possible acceptor sites for coupling of GPI proteins, or $P$. ramorum may lack enzymes that are required for GPI processing and cell wall incorporation of GPI proteins. $S$. cerevisiae possesses two GPI proteins, Dfg5p and Dcw1p, that have homology with bacterial endomannosidases. Because these proteins are predicted to be located at the plasma mem- 
brane, they might be involved in cleavage of GPI anchors from GPI proteins that are destined to be incorporated into the cell wall. This is supported by the observation that baker's yeast cells partially deficient in Dfg5p and Dcw1p secrete increased amounts of Cwp1p, a normally abundant cell-wall-bound GPI protein that concentrates in the birth scar, into the medium (Kitagaki et al. 2002; Smits et al. 2006). P. ramorum has no obvious orthologs of Dfg5p and Dcw1p, indicating that this organism may lack enzymes essential for the incorporation of GPI proteins in cell walls.

In this study, release of CWPs from the cell wall matrix of strain Pr04 was investigated by incubating walls with Quantazyme, a protease-free 1,3- $\beta$-glucanase, or with mild alkali (30 mM NaOH), followed by MS/MS. In both cases, no release of CWPs was observed. The observation that these protocols for extracting fungal CWPs were ineffective for Phytophthora mycelium suggests that Phytophthora spp. contain a mechanism for retention of CWPs that is different from yeasts. Because 1,3- $\beta$-glucan is the major cell wall component in various Phytophthora spp. (Bartnicki-Garcia and Wang 1983), the inability of Quantazyme to extract detectable amounts of CWPs may suggest that proteins themselves cross-link into a water-insoluble SDS-resistant network.

\section{Concluding remarks.}

In recent years, considerable progress has been made in the understanding of the biology, pathology, and genetics of oomycetes in general and Phytophthora spp. in particular. This report describes the first cell wall proteomics approach based on the genome sequence of a Phytophthora sp. The procedure described here exemplifies the impact of novel, genome-based approaches toward control of Phytophthora infections. Analysis of CWPs is fast, easily applicable, and amenable to highthroughput procedures. Furthermore, it not only indicates whether genes are transcribed but also whether the transcripts are translated and the proteins incorporated into the cell wall. Although we cannot exclude the possibility that some CWPs may remain unidentified, the method is sensitive and reproducible, as shown by the identification of similar sets of proteins in different $P$. ramorum strains. The absence of GPI CWPs was illustrated by the inability to release CWPs with Quantazyme, and was confirmed by the absence of GPI anchor-addition sequences in any of the identified CWPs.

This study is the first inventory of Phytophthora CWPs. Investigation of wall extracts of tissues grown under different conditions and from different developmental stages will result in the identification of additional, differentially regulated CWPs. Most of the identified CWPs could be categorized into functional groups with predicted biochemical or biological functions; however, these remain to be experimentally validated. Until then, classifications are based on sharing conserved domains with homologous proteins that are suggestive of their function. Interestingly, examination of expression of the $P$. sojae orthologs, based on the presence of ESTs, revealed that 14 of the 17 genes are expressed in infected plant tissue, suggesting a role in pathogenicity (data not shown). With the rapidly increasing amount of genome and proteome information at hand, the challenge will be to validate these functions and to elucidate their biological role.

\section{MATERIALS AND METHODS}

\section{Strains and media.}

The isolates used in this study are strain CBS 101553, isolated from Rhododendron catawbiense in Germany; strain CBS 110536 (Pr04), isolated from Quercus kelloggii in Marin County, CA, U.S.A. (Ivors et al. 2004); strain CBS 110534
(Pr01), isolated from Quercus agrifolia in California, U.S.A. (Kroon et al. 2004), and PD 20023604, isolated from Viburnum bodnantense cv. Dawn in The Netherlands (Werres and Kaminski 2005). Isolates were obtained from the Centraalbureau voor Schimmelcultures (CBS; Fungal Biodiversity Centre, Utrecht, The Netherlands) and from the Plantenziektekundige Dienst (PD; Wageningen, The Netherlands). Isolates were grown in the dark on liquid Plich medium for 12 days at $18^{\circ} \mathrm{C}$. Plich medium was prepared as described previously (Van der Lee et al. 1997). The Plich medium was inoculated with mycelium on rye sucrose agar plugs (Caten and Jinks 1968) from actively growing colony margins of cultures. Mycelium was harvested and dried by pressing between filter paper.

\section{Cell wall isolation.}

Mycelia were ground in a Braun Microdismembrator U (B. Braun Biotech International $\mathrm{GmbH}$, Melsungen, Germany), re-

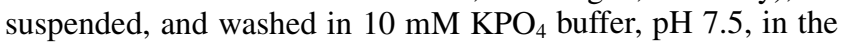
presence of a complete protease inhibitor cocktail (1873580, Roche, Branchburg, NJ, U.S.A.; 1 tablet in $50 \mathrm{ml}$ plus $30 \mu \mathrm{g}$ of pepstatin). Ground cell material was resuspended in $10 \mathrm{mM}$ Tris- $\mathrm{HCl}, \mathrm{pH} 7.5$ (plus protease inhibitors), and further disintegrated with 0.25 - to $0.50-\mathrm{mm}$ (diameter) glass beads (Emergo BV, Landsmeer, The Netherlands) using a Bio-Savant Fast Prep 120 machine (Qbiogene, Carlsbad, CA, U.S.A.). Noncovalently linked proteins and intracellular contaminants were removed by washing the isolated cell walls extensively with 1 $\mathrm{M} \mathrm{NaCl}$ followed by extraction (twice) in $50 \mathrm{mM}$ Tris- $\mathrm{HCl}$, $\mathrm{pH} 7.8,2 \%$ SDS, $100 \mathrm{mM}$ Na-EDTA, and $40 \mathrm{mM} \beta$-mercaptoethanol for $5 \mathrm{~min}$ at $100^{\circ} \mathrm{C}$. The SDS-treated cell walls were washed three times with water and lyophilized.

\section{Cell wall composition analysis.}

For determination of cell wall carbohydrates, the polysaccharides in cell wall preparations were hydrolyzed using sulfuric acid (Dallies et al. 1998). Briefly, $4 \mathrm{mg}$ of lyophilized cell walls were incubated with $100 \mu \mathrm{l}$ of $72 \%(\mathrm{vol} / \mathrm{vol}) \mathrm{H}_{2} \mathrm{SO}_{4}$ for $3 \mathrm{~h}$ at room temperature. Samples were then diluted with $575 \mu \mathrm{l}$ of distilled $\mathrm{H}_{2} \mathrm{O}$ to obtain a $2 \mathrm{M} \mathrm{H}_{2} \mathrm{SO}_{4}$ solution and incubated for $4 \mathrm{~h}$ at $100^{\circ} \mathrm{C}$. Samples were analyzed by HPLC (LKB) on a REZEX organic acid analysis column (Phenomenex, Torrance, CA, U.S.A.) at $40^{\circ} \mathrm{C}$ with $7.2 \mathrm{mM} \mathrm{H}_{2} \mathrm{SO}_{4}$ as eluent, using an RI 1530 refractive index detector (Jasco, Great Dunmow, U.K). The chromatograms were analyzed using AZUR chromatography software and compared with chromatograms of known amounts of mannose, glucose, galactose, and glucosamine. Protein and chitin contents in the cell wall were determined following the protocols described by Kapteyn and associates (2001).

\section{Cell wall protein extraction.}

Two extraction methods that are known to solubilize covalently bound CWPs in yeasts (De Groot et al. 2004; Kapteyn et al. 1999) were applied to $P$. ramorum. For enzymatic release of CWPs, SDS-treated cell walls were incubated overnight with Quantazyme (30 units/mg) (Qbiogene, Morgan Irvine, CA, U.S.A.), a recombinant endo-1,3- $\beta$-glucanase, followed by dialysis against $\mathrm{H}_{2} \mathrm{O}$ and lyophilization of the solubilized material. For release of proteins that may be bound to the cell wall through a linkage that is sensitive to mild alkali, cell walls were incubated with $30 \mathrm{mM} \mathrm{NaOH}$ at $4^{\circ} \mathrm{C}$ for $17 \mathrm{~h}$ (Mrsa et al. 1997). The reaction was stopped by adding neutralizing amounts of acetic acid, followed by dialysis and lyophilization of released protein.

\section{Sample preparation for MS analysis.}

Cell walls and unfractionated protein extracts were reduced with dithiothreitol and S-alkylated with iodoacetamide as de- 
scribed previously (Shevchenko et al. 1996; Yin et al. 2005). Samples were digested with sequencing grade trypsin (Roche Molecular Biochemicals) overnight at $37^{\circ} \mathrm{C}$ with an estimated CWP/trypsin ratio of 50:1. Extracted peptides were desalted and concentrated on a $\mu \mathrm{C} 18$ ZipTip column (Millipore, Bedford, MA, U.S.A.).

\section{MS analysis.}

Solubilized peptides were analyzed by nanoscale HPLC electrospray ionization quadrupole time-of-flight LC/MS/MS using an Ultimate nano-LC system (Dionex, Sunnyvale, CA, U.S.A.) and a MicroMass Q-TOF mass spectrometer (Waters, Milford, MA, U.S.A.). Proteolytic digests derived from $40 \mu \mathrm{g}$ of lyophilized cell walls were injected with a micro-autosampler (FAMOS) on a precolumn (300- $\mu \mathrm{m}$ inner diameter by $5 \mathrm{~mm})$. Thereafter, the peptides were loaded and separated on a PepMap column $(75-\mu \mathrm{m}$ inner diameter by $150 \mathrm{~mm}$; Dionex). A linear gradient of 5 to $95 \% \mathrm{~B}$, where mobile phase A was water $+0.1 \%$ formic acid and mobile phase $\mathrm{B}$ was acetonitrile $+0.1 \%$ formic acid, over 30 min was employed for separation at a flow rate of $300 \mathrm{nl} / \mathrm{min}$. Online coupling to the Q-TOF was present using a coated fused-silica PicoTip (FS360-20-10CE; New Objective, Woburn, MA, U.S.A.). Masslynx software automatically selected peptides from the survey spectrum for collision-induced fragmentation. Fragmentation was achieved with argon as collision gas at a pressure of $4 \times 10^{-5}$ bar measured on the quadrupole pressure gauge. MS/MS spectra were analyzed with Masslynx Pepseq software to generate peak lists. These data were used to search the $P$. ramorum proteome database with the Mascot search engine (version 2.0; Matrix Science website). The $P$. ramorum proteome is available at the website of the DOE Joint Genome Institute (JGI). To identify $N$-terminal peptides, signal peptidase cleavage sites were predicted using SignalP 3.0 server (Bendtsen et al. 2004) and sequences of matured proteins were added to the proteome file. The Mascot searching parameters consisted of allowing up to one missed cleavage, fixed carbamidomethyl modification, a peptide tolerance of $2.0 \mathrm{Da}$, and an MS/MS tolerance of 0.8 Da. Probability-based Mascot scores were used to evaluate protein identifications. Only matches with $P<0.05$ for random occurrence were considered significant.

\section{Database analysis.}

Genes encoding the identified proteins were analyzed with the publicly accessible databases at the JGI of the United States Department of Energy or the Virginia Bioinformatics Institute microbial database (Tripathy et al. 2006). The databases contain a functional assignment based on automatic analysis. For additional functional assignment and homology studies, searches were initiated in publicly available datasets. Conserved domains were retrieved directly from the JGI database and also based on analyses using multiple databases including SMART, NCBI, and Interproscan. Signal peptides were detected via SignalP using default parameters (Bendtsen et al. 2004). Transmembrane regions identified by SMART or Interproscan were verified by using the PredCon II program (Arai et al. 2004). For GPI lipid anchor prediction, big-PI plant predictor (Eisenhaber et al. 2003) was used. Repeats in proteins were investigated with rapid automatic detection and alignment of repeats, available at the European Bioinformatics Institute. Alignments were performed using the CLUSTAL program (version 1.83). Glycoside hydrolases are classified according to the carbohydrate-active enzymes database.

\section{ACKNOWLEDGMENTS}

The authors gratefully acknowledge the Department of Energy JGI for making the $P$. sojae and $P$. ramorum genome sequences publicly available.
This work was supported by grants to F. Govers by the Dutch Ministry of Agriculture, Nature and Food Quality (LNV427) and the Technology Foundation STW (WPB.5498) and to F. M. Klis from the European Union (FUNGWALL). The Q-TOF mass spectrometer has been funded largely by the Council for Medical Sciences of the Netherlands Organization for Scientific Research (NWO-ZonMW). The nano HPLC was funded by a grant from the Council for Chemical Sciences of The Netherlands Organization for Scientific Research (NWO-CW). We thank M. Bekker and H. Dekker (UvA-SILS) for assistance with HPLC and mass spectrometric analysis, respectively.

\section{LITERATURE CITED}

Arai, M., Mitsuke, H., Ikeda, M., Xia, J. X., Kikuchi, T., Satake, M., and Shimizu, T. 2004. ConPred II: A consensus prediction method for obtaining transmembrane topology models with high reliability. Nucleic Acids Res. 32:W390-393.

Barre, A., Peumans, W. J., Menu-Bouaouiche, L., Van Damme, E. J., May, G. D., Herrera, A. F., Van Leuven, F., and Rouge, P. 2000. Purification and structural analysis of an abundant thaumatin-like protein from ripe banana fruit. Planta 211:791-799.

Bartnicki-Garcia, S., and Wang, M. C. 1983. Biochemical aspects of morphogenesis in Phytophthora. Pages 121-138 in: Phytophthora. D. C. Erwin, S. Bartinicki-Garcia, and P. H. Tsao, eds. American Phytopathological Society Press, St. Paul, MN, U.S.A.

Bates, S., Hughes, H. B., Munro, C. A., Thomas, W. P., MacCallum, D. M., Bertram, G., Atrih, A., Ferguson, M. A., Brown, A. J., Odds, F. C., and Gow, N. A. 2006. Outer chain N-glycans are required for cell wall integrity and virulence of Candida albicans. J. Biol. Chem. 281:90-98.

Bendtsen, J. D., Nielsen, H., von Heijne, G., and Brunak, S. 2004. Improved prediction of signal peptides: SignalP 3.0. J. Mol. Biol. 340:783795.

Birch, P. R., Rehmany, A. P., Pritchard, L., Kamoun, S., and Beynon, J. L. 2006. Trafficking arms: Oomycete effectors enter host plant cells. Trends Microbiol. 14:8-11.

Boissy, G., de La Fortelle, E., Kahn, R., Huet, J. C., Bricogne, G., Pernollet, J. C., and Brunie, S. 1996. Crystal structure of a fungal elicitor secreted by Phytophthora cryptogea, a member of a novel class of plant necrotic proteins. Structure 4:1429-1439.

Brownstein, C., Deora, A. B., Jacovina, A. T., Weintraub, R., Gertler, M., Khan, K. M., Falcone, D. J., and Hajjar, K. A. 2004. Annexin II mediates plasminogen-dependent matrix invasion by human monocytes: Enhanced expression by macrophages. Blood 103:317-324.

Brunner, F., Rosahl, S., Lee, J., Rudd, J. J., Geiler, C., Kauppinen, S., Rasmussen, G., Scheel, D., and Nürnberger, T. 2002. Pep-13, a plant defense-inducing pathogen-associated pattern from Phytophthora transglutaminases. EMBO (Eur. Mol. Biol. Organ.) J. 21:6681-6688.

Cassab, G. I. 1998. Plant cell wall proteins. Annu. Rev. Plant Physiol. Plant Mol. Biol. 49:281-309.

Caten, C. E., and Jinks, J. L. 1968. Spontaneous variability of single isolates of Phytophthora infestans. I. Cultural variation. Can. J. Bot. 46:329-348.

Cote, F., Ham, K. S., Hahn, M. G., and Bergmann, C. W. 1998. Oligosaccharide elicitors in host-pathogen interactions. Generation, perception, and signal transduction. Subcell. Biochem. 29:385-432.

Dallies, N., Francois, J., and Paquet, V. 1998. A new method for quantitative determination of polysaccharides in the yeast cell wall. Application to the cell wall defective mutants of Saccharomyces cerevisiae. Yeast 14:1297-1306.

Dean, R. A., Talbot, N. J., Ebbole, D. J., Farman, M. L., Mitchell, T. K., Orbach, M. J., Thon, M., Kulkarni, R., Xu, J. R., Pan, H., Read, N. D., Lee, Y. H., Carbone, I., Brown, D., Oh, Y. Y., Donofrio, N., Jeong, J. S., Soanes, D. M., Djonovic, S., Kolomiets, E., Rehmeyer, C., Li, W., Harding, M., Kim, S., Lebrun, M. H., Bohnert, H., Coughlan, S., Butler, J., Calvo, S., Ma, L. J., Nicol, R., Purcell, S., Nusbaum, C., Galagan, J. E., and Birren, B. W. 2005. The genome sequence of the rice blast fungus Magnaporthe grisea. Nature 434:980-986.

De Groot, P. W. J., De Boer, A. D., Cunningham, J., Dekker, H. L., de Jong, L., Hellingwerf, K. J., de Koster, C., and Klis, F. M. 2004. Proteomic analysis of Candida albicans cell walls reveals covalently bound carbohydrate-active enzymes and adhesins. Eukaryot. Cell 3:955-965.

De Groot, P. W. J., Hellingwerf, K. J., and Klis, F. M. 2003. Genome-wide identification of fungal GPI proteins. Yeast 20:781-796.

De Groot, P. W. J., Ram, A. F., and Klis, F. M. 2005. Features and functions of covalently linked proteins in fungal cell walls. Fungal Genet. Biol. 42:657-675.

Ecker, M., Deutzmann, R., Lehle, L., Mrsa, V., and Tanner, W. 2006. Pir proteins of Saccharomyces cerevisiae are attached to $\beta-1,3$-glucan by a new protein-carbohydrate linkage. J. Biol. Chem. 281:11523-11529. 
Eisenhaber, B., Schneider, G., Wildpaner, M., and Eisenhaber, F. 2004. A sensitive predictor for potential GPI lipid modification sites in fungal protein sequences and its application to genome-wide studies for Aspergillus nidulans, Candida albicans, Neurospora crassa, Saccharomyces cerevisiae and Schizosaccharomyces pombe. J. Mol. Biol. 337:243-253.

Fabritius, A. L., Cvitanich, C., and Judelson, H. S. 2002. Stage-specific gene expression during sexual development in Phytophthora infestans. Mol. Microbiol. 45:1057-1066.

Fabritius, A. L., and Judelson, H. S. 2003. A mating-induced protein of Phytophthora infestans is a member of a family of elicitors with divergent structures and stage-specific patterns of expression. Mol. PlantMicrobe Interact. 16:926-935.

Fefeu, S., Bouaziz, S., Huet, J. C., Pernollet, J. C., and Guittet, E. 1997. Three-dimensional solution structure of beta cryptogein, a beta elicitin secreted by a phytopathogenic fungus Phytophthora cryptogea. Protein Sci. 6:2279-2284.

Gipson, I. K. 2004. Distribution of mucins at the ocular surface. Exp. Eye Res. 78:379-388.

Gornhardt, B., Rouhara, I., and Schmelzer, E. 2000. Cyst germination proteins of the potato pathogen Phytophthora infestans share homology with human mucins. Mol. Plant-Microbe Interact. 13:32-42.

Grenier, J., Potvin, C., Trudel, J., and Asselin, A. 1999. Some thaumatinlike proteins hydrolyse polymeric beta-1,3-glucans. Plant J. 19:473480

Hahn, M. G. 1996. Microbial elicitors and their receptors in plants. Annu. Rev. Phytopathol. 34:387-412.

Henrissat, B. 1991. A classification of glycosyl hydrolases based on amino acid sequence similarities. Biochem. J. 280:309-316.

Henrissat, B., and Bairoch, A. 1993. New families in the classification of glycosyl hydrolases based on amino acid sequence similarities. Biochem. J. 293 781-788.

Henrissat, B., and Bairoch, A. 1996. Updating the sequence-based classification of glycosyl hydrolases. Biochem. J. 316:695-696.

Hicks, S. J., Theodoropoulos, G., Carrington, S. D., and Corfield, A. P. 2000. The role of mucins in host-parasite interactions. Part I-protozoan parasites. Parasitol. Today 16:476-481.

Hobson, R. P., Munro, C. A., Bates, S., MacCallum, D. M., Cutler, J. E., Heinsbroek, S. E., Brown, G. D., Odds, F. C., and Gow, N. A. 2004 Loss of cell wall mannosylphosphate in Candida albicans does not influence macrophage recognition. J. Biol. Chem. 279:39628-39635.

Howard, R. J., Ferrari, M. A., Roach, D. H., and Money, N. P. 1991. Penetration of hard substrates by a fungus employing enormous turgor pressures. Proc. Natl. Acad. Sci. U.S.A. 88:11281-11284.

Ivors, K. L., Hayden, K. J., Bonants, P. J., Rizzo, D. M., and Garbelotto, M. 2004. AFLP and phylogenetic analyses of North American and European populations of Phytophthora ramorum. Mycol. Res. 108:378392.

Jentoft, N. 1990. Why are proteins $O$-glycosylated? Trends Biochem. Sci. 15:291-294.

Jiang, R. H. Y. 2006. Footprints of evolution: The dynamics of effector genes in the Phytophthora genome. Ph.D. thesis, Wageningen University, The Netherlands.

Jiang, R. H. Y., Tyler, B. M., Whisson, S. C., Hardham, A. R., and Govers, F. 2006. Ancient origin of elicitin gene clusters in Phytophthora genomes. Mol. Biol. Evol. 23:338-351.

Kapteyn, J. C., Montijn, R. C., Vink, E., de la Cruz, J., Llobell, A., Douwes, J. E., Shimoi, H., Lipke, P. N., and Klis, F. M. 1996. Retention of Saccharomyces cerevisiae cell wall proteins through a phosphodiesterlinked beta-1,3-/beta-1,6-glucan heteropolymer. Glycobiology 6:337-

Kapteyn, J. C., ter Riet, B., Vink, E., Blad, S., De Nobel, H., Van Den Ende, H., and Klis, F. M. 2001. Low external pH induces HOG1-dependent changes in the organization of the Saccharomyces cerevisiae cell wall. Mol. Microbiol. 39:469-479.

Kapteyn, J. C., Van Egmond, P., Sievi, E., Van Den Ende, H., Makarow, M., and Klis, F. M. 1999. The contribution of the O-glycosylated protein Pir2p/Hsp150 to the construction of the yeast cell wall in wild-type cells and beta 1,6-glucan-deficient mutants. Mol. Microbiol. 31:18351844

Kitagaki, H., Wu, H., Shimoi, H., and Ito, K. 2002. Two homologous genes, DCW1 (YKL046c) and DFG5, are essential for cell growth and encode glycosylphosphatidylinositol (GPI)-anchored membrane proteins required for cell wall biogenesis in Saccharomyces cerevisiae. Mol. Microbiol. 46:1011-1022.

Klebl, F., and Tanner, W. 1989. Molecular cloning of a cell wall exo-beta1,3-glucanase from Saccharomyces cerevisiae. J. Bacteriol. 171:62596264

Klis, F. M., Mol, P., Hellingwerf, K. J., and Brul, S. 2002. Dynamics of cell wall structure in Saccharomyces cerevisiae. FEMS (Fed. Eur. Microbiol. Soc.) Microbiol. Rev. 26:239-256.
Kollár, R., Reinhold, B. B., Petráková, E., Yeh, H. J., Ashwell, G., Drgonova, J., Kapteyn, J. C., Klis, F. M., and Cabib, E. 1997. Architecture of the yeast cell wall. $\beta(1 \rightarrow 6)$-glucan interconnects mannoprotein, $\beta(1 \rightarrow)$ 3-glucan, and chitin. J. Biol. Chem. 272:17762-17775.

Kroon, L. P. N. M., Verstappen, E. C. P., Cox, L. F. F., Flier, W. G., and Bonants, P. 2004. A rapid diagnostic test to distinguish between American and European populations of Phytophthora ramorum. Phytopathology 94:613-620.

Makarova, K. S., Aravind, L., and Koonin, E. V. 1999. A superfamily of archaeal, bacterial, and eukaryotic proteins homologous to animal transglutaminases. Protein Sci. 8:1714-1719.

McLeod, A., Smart, C. D., and Fry, W. E. 2003. Characterization of 1,3beta-glucanase and 1,3;1,4-beta-glucanase genes from Phytophthora infestans. Fungal Genet. Biol. 38:250-263.

Menu-Bouaouiche, L., Vriet, C., Peumans, W. J., Barre, A., Van Damme, E. J., and Rouge, P. 2003. A molecular basis for the endo-beta 1,3-glucanase activity of the thaumatin-like proteins from edible fruits. Biochimie 85:123-131.

Moss, S. E., and Morgan, R. O. 2004. The annexins. Genome Biol. 5:219.

Mrsa, V., Seidl, T., Gentzsch, M., and Tanner, W. 1997. Specific labeling of cell wall proteins by biotinylation. Identification of four covalently linked $O$-mannosylated proteins of Saccharomyces cerevisiae. Yeast 13:1145-1154.

Munro, C. A., Bates, S., Buurman, E. T., Hughes, H. B., Maccallum, D. M., Bertram, G., Atrih, A., Ferguson, M. A., Bain, J. M., Brand, A., Hamilton, S., Westwater, C., Thomson, L. M., Brown, A. J., Odds, F. C., and Gow, N. A. 2005. Mnt1p and Mnt2p of Candida albicans are partially redundant alpha-1,2-mannosyltransferases that participate in O-linked mannosylation and are required for adhesion and virulence. $\mathrm{J}$. Biol. Chem. 280:1051-1060.

Nürnberger, T., Nennstiel, D., Jabs, T., Sacks, W. R., Hahlbrock, K., and Scheel, D. 1994. High affinity binding of a fungal oligopeptide elicitor to parsley plasma membranes triggers multiple defense responses. Cell 78:449-460.

Parker, J. E., Schulte, W., Hahlbrock, K., and Scheel, D. 1991. An extracellular glycoprotein from Phytophthora megasperma f. sp. glycinea elicits phytoalexin synthesis in cultured parsley cells and protoplasts. Mol. Plant-Microbe Interact. 4:19-27.

Prill, S. K., Klinkert, B., Timpel, C., Gale, C. A., Schroppel, K., and Ernst, J. F. 2005. PMT family of Candida albicans: Five protein mannosyltransferase isoforms affect growth, morphogenesis and antifungal resistance. Mol. Microbiol. 55:546-560.

Qutob, D., Kamoun, S., and Gijzen, M. 2002. Expression of a Phytophthora sojae necrosis-inducing protein occurs during transition from biotrophy to necrotrophy. Plant J. 32:361-373.

Rizzo, D. M., Garbelotto, M., Davidson, J. M., Slaughter, G. W., and Koike, S. T. 2002. Phytophthora ramorum as the cause of extensive mortality of Quercus spp. and Lithocarpus densiflorus in California. Plant Dis. 86:205-214.

Rose, J. K., Ham, K. S., Darvill, A. G., and Albersheim, P. 2002. Molecular cloning and characterization of glucanase inhibitor proteins: Coevolution of a counterdefense mechanism by plant pathogens. Plant Cell 14:1329-1345.

Sacks, W., Nürnberger, T., Hahlbrock, K., and Scheel, D. 1995. Molecular characterization of nucleotide sequences encoding the extracellular glycoprotein elicitor from Phytophthora megasperma. Mol. Gen. Genet. 246:45-55.

Sakamoto, Y., Watanabe, H., Nagai, M., Nakade, K., Takahashi, M., and Sato, T. 2006. Lentinula edodes $\operatorname{tg} 1$ encodes a thaumatin-like protein that is involved in lentinan degradation and fruiting body senescence. Plant Physiol. 141:793-801.

Sharom, F. J., and Lehto, M. T. 2002. Glycosylphosphatidylinositol-anchored proteins: Structure, function, and cleavage by phosphatidylinositol-specific phospholipase C. Biochem. Cell. Biol. 80:535-549.

Shevchenko, A., Wilm, M., Vorm, O., and Mann, M. 1996. Mass spectrometric sequencing of proteins silver-stained polyacrylamide gels. Anal. Chem. 68:850-858.

Showalter, A. M. 1993. Structure and function of plant cell wall proteins. Plant Cell 5:9-23.

Simmons, C. R. 1994. The physiology and molecular biology of plant 1,3beta-D-glucanases and 1,3;1,4-beta-D-glucanases. Crit. Rev. Plant Sci. 13:325-387.

Smits, G. J., Schenkman, L. R., Brul, S., Pringle, J. R., and Klis, F. M. 2006. Role of cell cycle-regulated expression in the localized incorporation of cell wall proteins in yeast. Mol. Biol. Cell. 17:3267-3280.

Solito, E., Nuti, S., and Parente, L. 1994. Dexamethasone-induced translocation of lipocortin (annexin) 1 to the cell membrane of U-937 cells. Br. J. Pharmacol. 112:347-348.

Sundstrom, P. 2002. Adhesion in Candida spp. Cell Microbiol. 4:461-469.

Theodoropoulos, G., Hicks, S. J., Corfield, A. P., Miller, B. G., and 
Carrington, S. D. 2001. The role of mucins in host-parasite interactions: Part II-helminth parasites. Trends Parasitol. 17:130-135.

Tian, M., Benedetti, B., and Kamoun, S. 2005. A second Kaza1-like protease inhibitor from Phytophthora infestans inhibits and interacts with the apoplastic pathogenesis-related protease P69B of tomato. Plant Physiol. 138:1785-1793.

Tian, M., Huitema, E., Da Cunha, L., Torto-Alalibo, T., and Kamoun, S. 2004. A Kazal-like extracellular serine protease inhibitor from Phytophthora infestans targets the tomato pathogenesis-related protease P69B. J. Biol. Chem. 279:26370-26377.

Torto-Alalibo, T., Tian, M., Gajendran, K., Waugh, M. E., van West, P., and Kamoun, S. 2005. Expressed sequence tags from the oomycete fish pathogen Saprolegnia parasitica reveal putative virulence factors. BMC Microbiol. 5:46.

Tripathy, S., Pandey, V. N., Fang, B., Salas, F., and Tyler, B. M. 2006. VMD: A community annotation database for oomycetes and microbial genomes. Nucleic Acids Res. 34:D379-D381.

Tyler, B. M., Tripathy, S., Zhang, X., Dehal, P., Jiang, R. H. Y., Aerts, A., Arredondo, F., Baxter, L., Bensasson, D., Beynon, J. L., Damasceno, C. M. B., Dickerman, A., Dorrance, A. E., Dou, D., Dubchak, I., Garbelotto, M., Gijzen, M., Gordon, S., Govers, F., Grunwald, N. J., Huang, W., Ivors, K., Jones, R. W., Kamoun, S., Krampis, K., Lamour, K., Lee, M.K., McDonald, W. H., Medina, M., Meijer, H. J. G., Nordberg, E., Maclean, D. J., Ospina-Giraldo, M. D., Morris, P. F., Phuntumart, V., Putnam, N., Rash, S., Rose, J. K. C., Sakihama, Y., Salamov, A. Savidor, A., Scheuring, C., Smith, B., Sobral, B. W. S., Terry, A., TortoAlalibo, T., Win, J., Xu, Z., Zhang, H., Grigoriev, I., Rokhsar, D., and Boore, J. 2006. Phytophthora genome sequences uncover evolutionary origins and mechanisms of pathogenesis. Science. 313:1261-1266.

Van der Lee, T., De Witte, I., Drenth, A., Alfonso, C., and Govers, F. 1997. AFLP linkage map of the oomycete Phytophthora infestans. Fungal Genet. Biol. 21:278-291.

Werres, S., and Kaminski, K. 2005. Characterisation of European and North American Phytophthora ramorum isolates due to their morphol- ogy and mating behaviour in vitro with heterothallic Phytophthora species. Mycol. Res. 109:860-871.

Werres, S., Marwitz, R., Man in 't Veld, W. A., de Cock, A. W. A. M. Bonants, P. J. M., De Weerdt, M., Themann, K., Ilievea, E., and Baayen, R. P. 2001. Phytophthora ramorum sp. nov., a new pathogen on Rhododendron and Viburnum. Mycol. Res. 105:1155-1165.

Westerink, N., Joosten, M. H. A. J., and de Wit, P. J. G. M. 2004. Fungal (A)virulence factors at the crossroads of disease susceptibility and resistance. Pages 93-127 in: Fungal Disease Resistance in Plants. Biochemistry, Molecular Biology and Genetic Engineering. Z. Punja, ed. Haworth Press, Binghamton, NY, U.S.A.

Xia, Y. 2004. Proteases in pathogenesis and plant defence. Cell Microbiol. 6:905-913.

Yin, Q. Y., de Groot, P. W. J., Dekker, H. L., de Jong, L., Klis, F. M., and de Koster, C. G. 2005. Comprehensive proteomic analysis of Saccharomyces cerevisiae cell walls: Identification of proteins covalently attached via glycosylphosphatidylinositol remnants or mild alkali-sensitive linkages. J. Biol. Chem. 280:20894-20901.

\section{AUTHOR-RECOMMENDED INTERNET RESOURCES}

Carbohydrate-active enzymes (CAZY) database: afmb.cnrs-mrs.fr/CAZY

DOE Joint Genome Institute (JGI) $P$. ramorum genome database: genome.jgi-psf.org/ramorum1/ramorum1.home.html

DOE JGI $P$. sojae genome database: genome.jgi-psf.org/sojae1/sojae1.home.html

DOE JGI T. pseudonana genome database: genome.jgi-psf.org/thaps1/thaps1.home.html

European Bioinformatics Institute (EBI): www.ebi.ac.uk/Radar/ Matrix Science Mascot search website: www.matrixscience.com United States Department of Energy JGI: www.jgi.doe.gov

The Virginia Bioinformatics Institute (VBI) microbial database: phytophthora.vbi.vt.edu 